\title{
Coconut Waste as a Source for Biodiesel Production
}

\author{
Sarina Sulaiman ${ }^{+1,2}$, Abdul Aziz Abdul Raman ${ }^{1}$ and Mohammed Kheireddine Aroua \\ ${ }^{1}$ Department of Chemical Engineering, Faculty of Engineering, \\ University of Malaya, Kuala Lumpur \\ ${ }^{2}$ Department of Chemical Engineering, Faculty of Engineering, \\ International Islamic University of Malaysia, Kuala Lumpur \\ Email:rin2207@yahoo.com
}

\begin{abstract}
Biodiesel industry needs a cheaper and economical viable raw material that can replace the currently used vegetable oil. Obtaining cheaper raw materials are one of the continuous targets of many biodiesel producing facilities since 70 to $95 \%$ of the production costs are attributed to raw materials. One of the main options is to use waste material from animal and plant sources. In this study, coconut waste is used to produce biodiesel using methanol and $\mathrm{KOH}$. The oil content in coconut waste varies from 10-11 wt\%. The highest yield, $64 \%$ is achieved with $5 \mathrm{wt} \%$ of $\mathrm{KOH}$ within $3 \mathrm{hr}$ by mixing raw material and methanol.
\end{abstract}

Keywords-wastes; biodiesel; production; raw material; extraction.

\section{INTRODUCTION}

Worldwide energy crisis due to depletion of resources and increased environmental problems has led to the search for an alternative fuel, which should be not only sustainable but also environment friendly. For developing countries, fuels of bio-origin, such as alcohol, vegetable oils, biomass, biogas, synthetic fuels are becoming important. Biodiesel derived from oil crops is a potential renewable and carbon neutral alternative to petroleum fuels. Technology for producing and using biodiesel has been known for more than 50 years. In the United States, biodiesel is produced mainly from soybeans. Other sources of commercial biodiesel feedstock includes sun flower oil [1, 2], animal fat [3], palm oil $[4,5]$, waste cooking oil $[6,7]$ and Jatropha oil $[8,9]$. Even, okra [10], Morienga [1], jojoba oil, castor oil and sesame oil [11] are used to produce biodiesel.

However, biodiesel from oil crops cannot realistically satisfy the existing demand for transport fuels and the price of vegetable oil is hiking as well. The high cost in production of biodiesel has become the major obstacle and the use of vegetable oil as raw material is competing with edible oils. Obtaining cheaper raw materials are one of the continuous targets of many biodiesel producing facilities since 70 to $95 \%$ of the production costs are attributed to raw materials [12]. One of the main options is to use waste material from animal and plant sources. There are few types of wastes used as raw materials in biodiesel production includes, waste bleaching earth, fryer grease oil/waste cooking oil, discarded marine parts, spent coffee ground and sludge. Waste lard and waste cooking oil contains the highest oil and is abundant and cheap. Table 1 shows the summary of oil content, type of catalyst, advantages and disadvantages of wastes for biodiesel production.

In Malaysia, the mostly available and accepted raw material for biodiesel production is palm oil. Other wastes, either waste oil or animal fats is not fully commercialized if compared to other countries. The reason is because low availability of waste and the waste collection is not fully exploited and are more scattered. The price of palm oil is far cheaper if compared to other raw materials and this become the main reason of lack of development of other raw material. However it is reported that 60 tons of waste vegetable oil are converted to biodiesel by Intrack Technology Sdn. Bhd, from Rawang in 2009. This company is looking forward into more research and improvement in the biodiesel before commercialization their biodiesel. Malaysia needs more development in the production of biodiesel by not only depending on the palm oil as the main raw material but to other raw material especially wastes in order to compete with other countries. There are abundant of waste cooking oil, fats and other vegetable wastes that can be fully utilized as cheap feedstock. To date, it is claimed that only Grand Inizio Sdn Bhd. has develop multi-feedstock biodiesel technology in January 2009 [13]. Lam MK, et al., 2010 reported that 0.5 tonne million/year of waste cooking oil is produced in Malaysia.

In these studies, the waste from coconut industries is used as the feedstock. In Malaysia estimated 3960 metric tons of coconut waste is being generated of which majority are from coconut oil waste and being used as fertilizer or to feed the cows or left to decompose on the fields. Typically coconut may still contain $10-15 \%$ extractable oil content and the FAME compositions are $\mathrm{C}_{8}$ to $\mathrm{C}_{12}$. This forms the justification of this work where methyl ester will be produced by directly subjecting the coconut waste with methanol and catalyst, $\mathrm{KOH}$. This study is conducted to determine the optimum reaction time and catalyst loading to produce the highest yield of biodiesel using in situ production.

\section{MATERIAL AND METHOD}

\section{A. Drying}

Coconut waste is dried overnight at $50^{\circ} \mathrm{C}$. After drying, the coconut is kept in dry cabinet for further usage. 


\section{B. Extraction}

Coconut waste is grinded to fine powder using grinder. All the experiment is carried out in $150 \mathrm{~mL}$ soxhlet extractor. Coconut is weighted and put into a thimble. The thimble is then put into the soxhlet distillation chamber and the extraction process is conducted for $5 \mathrm{hr}$. Hexane is used to separate the oil from the waste. .

\section{Insitu Production}

In situ production reactions are performed in $150 \mathrm{ml}$ jacketed batch reactor. The temperature is controlled by the water bath. The reaction is conducted at $50^{\circ} \mathrm{C}$. Coconut residue is mixed with methanol and $\mathrm{KOH}$ in the vessel for 5 hr. Finally, the oil and glycerin is separated using funnel. The oil is washed with warm water $\left(45-50^{\circ} \mathrm{C}\right)$.

\section{Analysis}

The biodiesel composition is analyzed using GC 6810 . The $0.1 \mathrm{~mL}$ of sample is diluted with $3.9 \mathrm{~mL}$ of $\mathrm{n}$-hexane and $1 \mathrm{vL}$ of sample is injected into DB 23 column. The standard mixture of fatty acid is bought from Sigma.

\section{RESULTS AND DISCUSSION}

Extraction of oil is carried out using n-hexane as the solvent. The oil yield varies slightly during the extraction of coconut residue. The yield of oil averaged 10 to $10.5 \mathrm{wt} \%$. This shows that even after the extraction of milk, there is 10 $w t \%$ of oil in the residue.

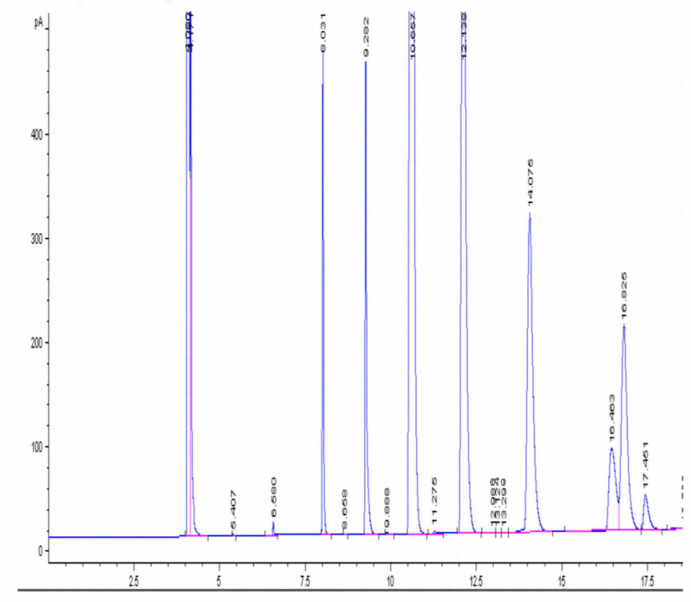

Figure 1. FAME composition of coconut residue biodiesel

\section{A. Effect of catalyst and time during in situ production}

The in situ production of biodiesel is conducted by mixing coconut residue, $150 \mathrm{ml}$ methanol, 1,3 and $5 \mathrm{wt} \%$ of catalyst and without adding any co solvent. Figure 2 shows the effect of catalyst and time on biodiesel yield. From the figure, the graph pattern shows that after 3 hours of reaction, the yield decreases. K-H. Chung et al., 2009 also reported the same finding that the optimum reaction occurs in 3 hour. Furthermore, the reaction with $1 \mathrm{wt} \%$ of catalyst does not complete because the yield are below $10 \%$. This is because the catalyst amount is not enough to support the reaction and a small amount of oil is separated. The highest yield, $64 \%$ is achieved at $3 \mathrm{hr}$ with $5 \mathrm{wt} \%$ of catalyst.

Increasing the catalyst from $1 \mathrm{wt} \%$ to $5 \mathrm{wt} \%$ increases the yield. The highest yield is when $5 \mathrm{wt} \%$ of catalyst is used. This shows that methanol can be used as a solvent but it is a weak co solvent.

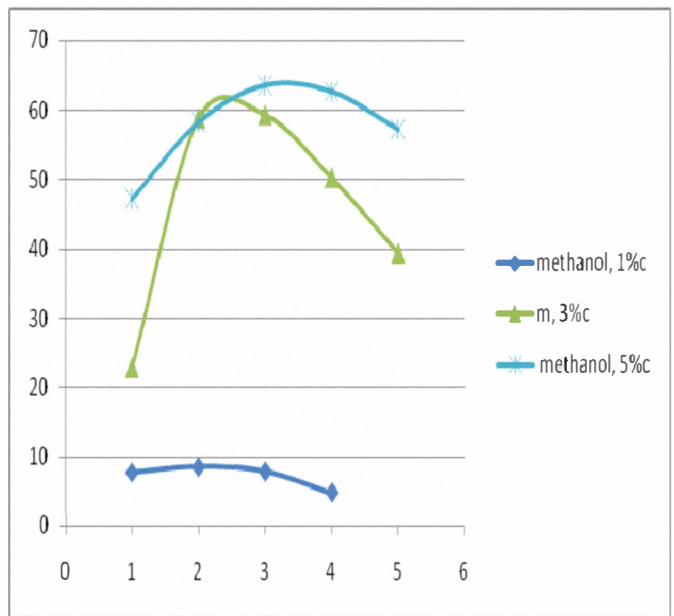

Figure 2. Effect of catalyst and time on biodiesel yield

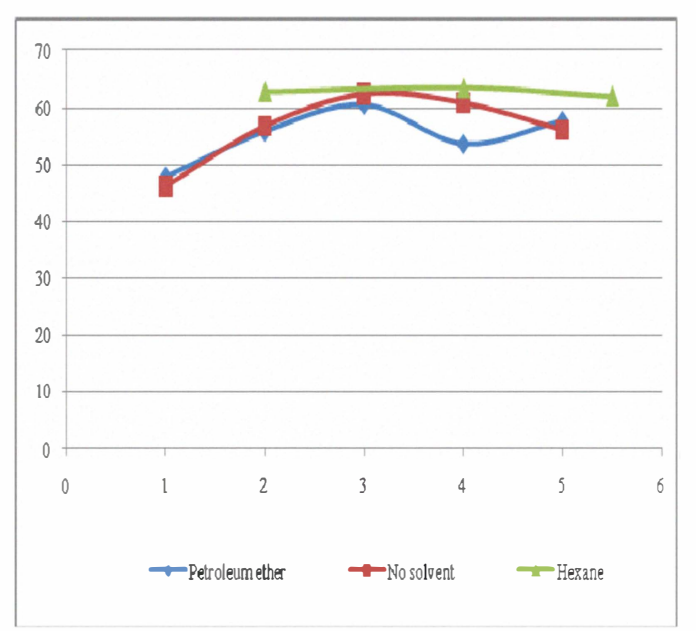

Figure 3. The relationship between co-solvent vs. reaction time

\section{B. Effect of different type of solvent}

Hexane and petroleum ether are used as co-solvent to enhance the oil extraction. The in situ reaction is conducted at $55^{\circ} \mathrm{C}$ and $5 \mathrm{wt} \%$ catalyst loading. Figure 3 shows the relationship between the hexane, petroleum ether and without solvent; versus time of reaction. The yield of biodiesel with hexane is slightly higher and more stable throughout the experiment while for the system with petroleum ether and without the solvent, the yield decreases after $3 \mathrm{hr}$. This shows that, hexane is a better solvent than petroleum ether. 


\section{CONCLUSION}

Coconut waste is a promising raw material that is cheap and abundant. There is $10-10.5 \mathrm{wt} \%$ of oil in coconut waste after the coconut milk extraction. The highest yield, $64 \%$ is achieved at $3 \mathrm{hr}$ with $5 \mathrm{wt} \%$ of catalyst. However, using hexane as a co-solvent increases the yield of biodiesel. The finding shows that in situ production eliminates the need to extract the oil and helps in cost reduction in production of biodiesel. In future, heterogeneous or acid catalyst can be used in order to achieve a higher yield.

\section{ACKNOWLEDGMENT}

This research is funded by PPP grant (PS401/2010A) from IPPP, University of Malaya, Malaysia.

\section{REFERENCES}

[1] U. Rashid, Anwar F, Moser BR, Ashraf S. Production of Sunflower Oil Methyl Esters By Optimized Alkali-Catalyzed Methanolysis. Biomass and Bioenergy (2008), Doi:10.1016/J.Biombioe.2008.03.001

[2] Sarin R, Malhotra RK, Et Al., Jatropha-Palm: Biodiesel Blends: An Optimum Mix for Asia, Fuel 86 (2007) 1365-1371.

[3] H.N. Bhatti, M A Hanif, M Qasim, A-u. Rehman. Biodiesel Production from Waste Tallow, Fuel 87 (2008), 2961-2966.

[4] O.J. Alamu, M.A. Waheed, S.O. Jekayinfa. Effect Of Ethanol-Palm Kernel Oil Ratio On Alkali-Catalyzed Biodiesel Yield, Fuel 87 (2008) 1529-1533.

[5] M. Aresta, Angela Dibenedetto, Maria Carone, Teresa Colonna, Carlo Fragale. Production of Biodiesel from Macroalgae by Supercritical
$\mathrm{CO} 2$ Extraction and Thermochemical Liquefaction, Environ Chem Lett 3 (2005) 136-139.

[6] J.M. Encinar , J.F. González, A. Rodríguez-Reinares. Ethanolysis of Used Frying Oil. Biodiesel Preparation And Characterization, Fuel Processing Technology 88 (2007) 513-522.

[7] M. M. Soumanou and Uwe T. Bornscheuer. Improvement in LipaseCatalyzed Synthesis of Fatty Acid Methyl Esters from Sunflower Oil, Enzyme and Microbial Technology 33 (2003) 97-103.

[8] S.Shah and M. N. Gupta. Lipase Catalyzed Preparation of Biodiesel from Jatropha Oil in A Solvent Free System, Process Biochemistry 42 (2007) 409-414.

[9] A.V. Tomasevic and S.S. Siler-Marinkovic. Methanolysis Of Used Frying Oil, Fuel Processing Technology 81 (2003) 1 -6.

[10] F. Anwar, U. Rashid, M. Ashraf and M. Nadeem. Okra (Hibiscus esculentus) seed oil for biodiesel production, Applied Energy, 87, Issue 3 (2010) 779-785.

[11] Karmakar, A., et al. Properties of various plants and animals feedstocks for biodiesel production. Bioresour. Technol. (2010), doi:10.1016/j.biortech.2010.04.079.

[12] Y. Zhang, M.A. Dub, D.D. McLean, M. Kates. Biodiesel production from waste cooking oil: 2 . Economic assessment and sensitivity analysis, Bioresource Technology 90 (2003) 229-240.

[13] S. Lim, L.K. Teong. Recent trends, opportunities and challenges of biodiesel in Malaysia: An overview, Renewable and Sustainable Energy Reviews 14 (2010) 938-954

[14] Lam M. K, Lee K. T. Lee, A.R.Mohamed. Homogeneous, heterogeneous and enzymatic catalysis for transesterification of high free fatty acid oil (waste cooking oil) to biodiesel: A review, Biotechnol Adv (2010), doi: 10.1016/j.biotechadv.2010.03.002.

[15] K-H. Chung, J. Kim, K-Y. Lee. Biodiesel Production By Transesterification Of Duck Tallow With Methanol On Alkali Catalysts, Biomass And Bioenergy 33 (2009)155-158. 